\title{
Preventive and Therapeutic Application of Molecular Hydrogen in Situations With Excessive Production of Free Radicals
}

\author{
J. SLEZÁK ${ }^{1}$, B. KURA ${ }^{1}$, K. FRIMMEL ${ }^{1}$, M. ZÁLEŠÁK ${ }^{1}$, T. RAVINGEROVÁ ${ }^{1}$, \\ C. VICZENCZOVÁ ${ }^{1}$, L. OKRUHLICOVÁ ${ }^{1}$, N. TRIBULOVÁ ${ }^{1}$ \\ ${ }^{1}$ Institute for Heart Research, Slovak Academy of Sciences, Bratislava, Slovakia
}

Received June 25, 2016

Accepted July 8, 2016

\section{Summary}

Excessive production of oxygen free radicals has been regarded as a causative common denominator of many pathological processes in the animal kingdom. Hydroxyl and nitrosyl radicals represent the major cause of the destruction of biomolecules either by a direct reaction or by triggering a chain reaction of free radicals. Scavenging of free radicals may act preventively or therapeutically. A number of substances that preferentially react with free radicals can serve as scavengers, thus increasing the internal capacity/activity of endogenous antioxidants and protecting cells and tissues against oxidative damage. Molecular hydrogen $\left(\mathrm{H}_{2}\right)$ reacts with strong oxidants, such as hydroxyl and nitrosyl radicals, in the cells, that enables utilization of its potential for preventive and therapeutic applications. $\mathrm{H}_{2}$ rapidly diffuses into tissues and cells without affecting metabolic redox reactions and signaling reactive species. $\mathrm{H}_{2}$ reduces oxidative stress also by regulating gene expression, and functions as an anti-inflammatory and anti-apoptotic agent. There is a growing body of evidence based on the results of animal experiments and clinical observations that $\mathrm{H}_{2}$ may represent an effective antioxidant for the prevention of oxidative stress-related diseases. Application of molecular hydrogen in situations with excessive production of free radicals, in particular, hydroxyl and nitrosyl radicals is relatively simple and effective, therefore, it deserves special attention.

\section{Key words}

Oxygen and nitrogen free radicals - Cardiovascular system • Oxidative stress • Inflammation • Apoptosis • Gene expression • Molecular hydrogen $\bullet$ Protection

\section{Corresponding author}

J. Slezák, Institute for Heart Research, Slovak Academy of Sciences, Dúbravská cesta 9, 84005 Bratislava, Slovakia. E-mail: jan.slezak@savba.sk

\section{Introduction}

Excessive production of reactive oxygen species (ROS) has been regarded as a common denominator of many pathological processes. Hydroxyl and nitrosyl radicals are the major cause of the destruction of biomolecules either by a direct action or by triggering the chain reaction of free radicals. Scavenging of excessive levels of ROS may result in preventive or therapeutic effects. A number of substances can serve as scavengers that increase the capacity/activity of endogenous antioxidants thereby augmenting cells and tissues protection against oxidative damage.

Targeted application of molecular hydrogen $\left(\mathrm{H}_{2}\right)$ as one of the potent scavengers may be used in the prevention and treatment of ROS-related diseases. $\mathrm{H}_{2}$ reacts with strong oxidants, such as hydroxyl and/or nitrosyl radicals that makes it possible to utilize its potential for preventive and therapeutic applications. $\mathrm{H}_{2}$ rapidly diffuses into tissues and cells, without affecting metabolic redox reactions and signaling ROS. $\mathrm{H}_{2}$ is able to reduce oxidative stress also by regulating gene expression, and acts as an anti-inflammatory and anti-apoptotic agent.

There is a growing body of evidence based on animal experiments and clinical observations that $\mathrm{H}_{2}$ may represent an effective antioxidant used for the prevention of oxidative stress-related pathologies. 


\section{States with increased production of free radicals}

Regulation of cellular redox balance is important for the maintenance of human body integrity. Many important diseases, such as ischemia, cancer, inflammation, diabetes and others and also ageing are known to be associated with increased ROS production (Majzunova et al. 2013).

Oxidative stress occurs due to the imbalance between the production of reactive oxygen and nitrogen species and the capability of innate biological systems to eliminate reactive intermediates. Numerous studies (Halliwell and Gutteridge 1992, Citrin et al. 2010, Slezak et al. 2015, Patel et al. 2016) have reported beneficial effects of a therapy with different antioxidant agents acting through different mechanisms and thus preventing cell damage.

The process of excessive ROS generation causes cellular damage and loss of physiological functions of cells and tissues linked with multiple pathologies. On the other hand, short-lasting or moderate oxidative stress is desirable to mediate signaling mechanisms regulating a variety of physiological processes (Sies 1997, Bell et al. 2007, Klandorf and van Dyke 2012).

The primary ROS are mostly generated by electron leakage from the mitochondrial electron transport chain (Lin and Beal 2006). Cellular redox homeostasis is a delicate balance between ROS production and the antioxidant innate system (Brewer et al. 2013).

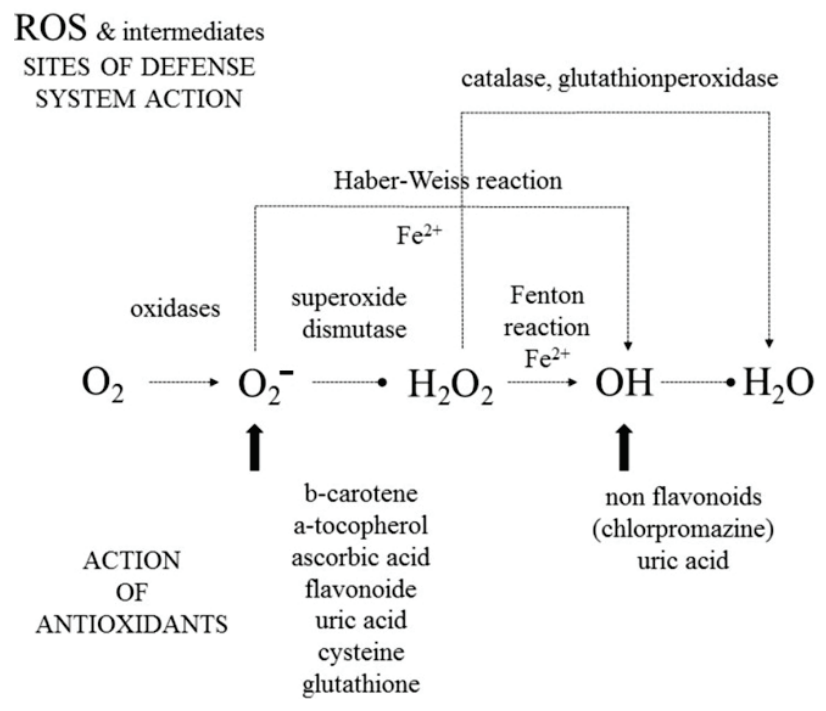

Fig. 1. ROS and intermediates sites of defense system action.
Superoxide dismutase (SOD) enzymatically converts ${ }^{\bullet} \mathrm{O}_{2}{ }^{-}$to hydrogen peroxide $\left(\mathrm{H}_{2} \mathrm{O}_{2}\right)$, which is metabolized to generate water $\left(\mathrm{H}_{2} \mathrm{O}\right)$. Very reactive ${ }^{\bullet} \mathrm{OH}$ is generated from $\mathrm{H}_{2} \mathrm{O}_{2}$ via the Fenton or Haber-Weiss reaction in the presence of catalytically active metals, such as $\mathrm{Fe}^{2+}$ and $\mathrm{Cu}^{2+}$ (Fig. 1) (Halliwell and Gutteridge 1992) or other redox-cycling compounds, which can cause damage to cells or tissues. The extent of the antioxidant depression is the key factor of cell viability where small antioxidant perturbations are readily corrected by the cell, but a large-scale depletion of antioxidants can cause cell death. DNA is a main target of this damage and its origin could be either somatic or mitochondrial. Mitochondrial DNA repair is less complete than chromosomal DNA repair. Damage to mitochondrial DNA is important for producing energy in the form of ATP, therefore, it can limit energy production leading to apoptosis and necrosis (Klandorf and van Dyke 2012).

${ }^{\bullet} \mathrm{OH}$ is the major cause of the oxidation and destruction of biomolecules by the direct reaction or by triggering the chain reaction of free radicals. Ionizing radiation including cosmic rays also generates ${ }^{\bullet} \mathrm{OH}$ as a damaging intermediate through the interaction with water, a process termed radiolysis (Schoenfeld et al. 2012). ${ }^{\circ} \mathrm{OH}$ is strong enough to react with $\mathrm{H}_{2}$, on the other hand, ${ }^{\bullet} \mathrm{O}_{2}{ }^{-}, \mathrm{H}_{2} \mathrm{O}_{2}$, and ${ }^{\bullet} \mathrm{NO}$ are insufficient to react with $\mathrm{H}_{2}$ (Ohta 2014).

In situation of the oxidative stress under physiological conditions, cells are able to increase the activities of antioxidant enzymes and other defense mechanisms to counteract effects of ROS. These include manganese-dependent superoxide dismutase (Mn-SOD), copper/zinc superoxide dismutase ( $\mathrm{Cu} / \mathrm{Zn}-\mathrm{SOD})$, glutathione peroxidase, glutathione reductase and catalase (CAT). Mn-SOD and $\mathrm{Cu} / \mathrm{Zn}-\mathrm{SOD}$ convert ${ }^{\circ} \mathrm{O}_{2}{ }^{-}$to hydrogen peroxide, which is then transformed to water by glutathione peroxidase or catalase (Halliwell and Gutteridge 1992).

General antioxidant defense is also provided by low molecular weight antioxidants, which are hydrogen atom-donating reducing agents such as ascorbic acid, tocopherols, polyphenols, and thiols such as glutathione. In such situation, the oxidants are neutralized by hydrogen atom donation, resulting in formation of a less reactive or nonreactive product from the original oxidant and a radical product from the antioxidant, which no longer can exert detrimental effects (Citrin et al. 2010, Slezak et al. 2015). 
Acute oxidative stress occurs in different situations, such as inflammation, cardiac or cerebral ischemia, organ transplantation and others (Reuter et al. 2010, Vaziri and Rodriguez-Iturbe 2006). On the other hand, evidence has established strong links between chronic oxidative stress and numerous pathologies including oncological diseases, diabetes mellitus, atherosclerosis, and chronic inflammatory processes, as well as many neurodegenerative diseases and the process of aging (Ohta 2014).

\section{Non-free radical species}

Oxidative stress is implicated in the pathophysiology of multiple conditions including cardiovascular diseases (CVD). Although the harmful cellular effects of free radicals in vitro remain undisputed, observational evidence along with clinical trials of free radical scavengers has been disappointing (Steinhubl 2008, Bjelakovic et al. 2007, Pechanova and Simko 2009, Patel et al. 2016).

This has promoted the concept that free radicals may not constitute clinically important sources of oxidants and that non-free radical species may be of equal or greater importance (Jones 2008, Go and Jones 2013, Jones and Liang 2009).

Cysteine represents the major aminothiol pool extracellularly that reacts easily with oxidants to form oxidized disulphide cystine. Intracellularly, glutathione is a major antioxidant that helps to eliminate peroxides and maintain cellular redox state, and its oxidized form is glutathione disulfide. Increased oxidative stress, measured as higher levels of cystine, lower levels of glutathione, or altered ratios of oxidized to reduced aminothiols, is associated with cellular dysfunction, aging and risk factors of cardiovascular diseases (Patel et al. 2016).

\section{Physiological role of $\mathrm{H}_{2} \mathrm{O}_{2}$ and signaling}

Oxidative stress and/or nitrosative stress caused by $\mathrm{H}_{2} \mathrm{O}_{2}$ and ${ }^{\circ} \mathrm{NO}$ induces enzymes involved in antioxidation and tolerance to protect cells against oxidative damage (Endo et al. 2009, Jazwa and Cuadrado 2010). There have been numerous reports highlighting the importance of ROS-dependent signaling in a variety of systems (Collins et al. 2012).

$\mathrm{H}_{2} \mathrm{O}_{2}$ is a key factor to regulate cellular differentiation (Tsukagoshi et al. 2010, Tormos et al. 2011), the immune system (West et al. 2011, Zhou et al. 2011), autophagy (Li et al. 2012, Garg et al. 2013) and apoptosis (Matés et al. 2012). Thus, it is crucial not to completely eliminate $\mathrm{H}_{2} \mathrm{O}_{2}$ to maintain homeostasis (Ohta et al. 2014).

\section{Selected situations with established excessive production of ROS}

\section{Ischemia and reperfusion}

Ischemia and reperfusion $(\mathrm{I} / \mathrm{R})$ is a major cause for inducing acute oxidative stress. In ischemic myocardium, accelerated generation of ROS through incomplete reduction of oxygen upon reperfusion is a potential mediator of reperfusion injury (Bolli et al. 1988, 1989, Zweier 1988, Vanden Hoek et al. 2000). ROS are produced by different cellular mechanisms, and their accumulation in the myocardium is generally considered to result in deleterious effects. These oxygen species are highly reactive and can quickly overwhelm the cell's endogenous free radical scavenging system. This, in turn, triggers cellular injury by reactions with lipids, proteins, and nucleic acids. The enzyme, xanthine oxidase, has been particularly implicated as a generator of free radicals in the reperfused heart, as its substrates (xanthine and hypoxanthine) accumulate during ischemia (Xia and Zweier 1995). The central role of ROS in reperfusion injury was demonstrated in studies showing that inhibitors of mitochondrial respiratory complexes I and III prevented reperfusion ROS generation and improved cellular viability.

ROS mediate myocardial injury by inducing mitochondrial permeability transition pore opening, causing a loss of mitochondrial membrane potential, and leading to mitochondrial swelling with membrane rupture (Halestrap et al. 2007). Targeting mitochondria with the effective antioxidant could prevent mitochondrial permeability transition pore opening when ROS are produced during early phase of heart reperfusion, however, this therapy failed to abrogate pathological cascade of oxidative damage after reperfusion injury (Zhang et al. 2012).

The pathogenesis of myocardial $\mathrm{I} / \mathrm{R}$ injury reflects the confluence of multiple pathways including ion channels, reactive oxygen species, inflammation, and endothelial dysfunction. Despite its complexity it is necessary to look for the possibility to mitigate this form of injury because many patients annually undergo either spontaneous or iatrogenic I/R events (Turer and Hill 2010).

Many attempts have been made to inhibit ROS production to limit the extent of reperfusion injury. The 
administration of ROS scavengers at the time of reperfusion has brought conflicting results that can be partially explained by the dual role of ROS in $I / R$ (Flaherty et al. 1994), since ROS play an important role as signaling molecules as well.

The majority of detrimental effects associated with lethal reperfusion injury are attributed to ${ }^{\bullet} \mathrm{OH}$. By comparison, ${ }^{\bullet} \mathrm{O}_{2}{ }^{-}$and $\mathrm{H}_{2} \mathrm{O}_{2}$ have less oxidative energy and, paradoxically, are implicated as crucial signaling components in the establishment of tolerance to oxidative stress (Ristow and Zarse 2010). Thus, cytotoxic radicals such as ${ }^{\circ} \mathrm{OH}$ must be neutralized without compromising the essential biological activities of other ROS and/or nitrosyl radicals, including ${ }^{\circ} \mathrm{NO}$ (Penna et al. 2006, Downey and Cohen 2006).

Increased production of ROS and failure of the antioxidant defense system are considered to play a central role in the pathogenesis of cardiovascular disease. The transcription factor nuclear factor (erythroidderived 2)-like 2 (Nrf2) is a key master switch controlling the expression of antioxidant and protective enzymes, and was proposed to participate in protection of vascular and cardiac function. The central role of $\mathrm{Nrf} 2$ in maintenance of tissue redox balance, and Nrf2-dependent biochemical pathways may play an important role in preservation of cardiac and vascular function (Erkens et al. 2015).

\section{Preconditioning and postconditioning}

Strategy of myocardial protection based on the exploitation of the heart's own intrinsic protective mechanisms is known as preconditioning. Apart from the short-lasting protection afforded by classical ischemic preconditioning (IP) or its delayed ("second window") phase, adaptation to longer-lasting physiological stimuli or pathological processes is also known to increase myocardial resistance to ischemic injury. Although molecular mechanisms of cardiac adaptation conferring a higher ischemic tolerance still remain not sufficiently elucidated, multiple cascades of intracellular signalization are suggested to be involved in this process (Ravingerová 2007, 2012). Suppression of ROS production during IP procedure by antioxidant $\mathrm{N}$-acetylcysteine and by mitochondrial $\mathrm{K}_{\mathrm{ATP}}$ channel (mito $\mathrm{K}_{\mathrm{ATP}}$ ) blocker 5-hydroxydecanoate blunted cardioprotective effect of IP indicating an important role of ROS in preconditioning signaling cascades linked with mito $\mathrm{K}_{\mathrm{ATP}}$ opening (Matejíková et al. 2009).

Myocardial ischemic postconditioning afforded by brief episodes of $\mathrm{I} / \mathrm{R}$ applied immediately after the ischemic insult enhances resistance to lethal $I / R$ injury as well. Cardioprotection is conveyed by parallel pro-survival signaling pathways converging on mitochondria to prevent mitochondria permeability transition pore opening. Research indicated that postconditioning is associated with free radicals generation including nitric oxide $\left({ }^{\circ} \mathrm{NO}\right)$ and superoxide $\left({ }^{\bullet} \mathrm{O}_{2}^{-}\right)$, and that cardioprotection is blunted by antioxidants. Since ${ }^{\bullet} \mathrm{NO}$ and ${ }^{\bullet} \mathrm{O}_{2}^{-}$react to form peroxynitrite, it was hypothesized that postconditioning might trigger the formation of peroxynitrite to promote cardioprotection. Peroxynitrite generated in the myocardium during postconditioning activated cardioprotective mechanisms improving both structural and functional integrity of the left ventricle exposed to ischemia and reperfusion in vivo (Li et al. 2013).

\section{Radiation}

Mechanisms by which radiation causes tissue injury of both malignant and normal tissues involves induction of apoptosis due to free radical-mediated DNA damage, and the sequence of overlapping events that include activation of the coagulation system, inflammation, and tissue remodeling. This complex process is orchestrated by a large number of interacting molecular signals including cytokines, chemokines, and growth factors. Radiation affects tissues by direct and indirect effects.

Direct action. DNA is the principle target of biological effects of radiation. Radiation may damage the DNA directly, causing ionization of the atoms in the DNA molecule. Increased expression of pro-inflammatory and other genes has been demonstrated within hours following irradiation (Hong et al. 1995, Kyrkanides et al. 2002). These include genes of transcription factors such as nuclear factor-kappa B $(\mathrm{NF}-\kappa \mathrm{B})$, cytokines, such as tumor necrosis factor- $\alpha$ (TNF $\alpha$ ), interleukin-1 $\beta$ (IL-1 $\beta$ ), and basic fibroblast growth factor (bFGF) involved in inflammatory processes (Slezak et al. 2015). Radiation treatment causes also direct damage to blood vessels by the generation of ROS that disrupt DNA strands and leading to an inflammatory cascade (Hatoum et al. 2006, Slezak et al. 2015).

Indirect action via production of free oxygen radicals. Radiation interacts with non-critical target atoms or molecules, usually water. This results in the production of free radicals. Free radicals can then attack critical targets such as the DNA, because they are able to penetrate the cell. The initial ionization event does not have to occur so 
close to the DNA in order to cause damage.

The 'law of Bergonié and Tribondeau' formulated in 1906 declares that X-rays are more effective in the cells which have a greater reproductive activity that any cells that are immature. Undifferentiated and actively dividing cells are more radiosensitive than mature non-dividing cells. A radiosensitive cell would have a greater chance of death after exposure to ionizing radiation than a radioresistant cell. Experiments have shown that the effects of ionizing radiation on a cell also depend on the total dose and exposure rate. A large dose given within a short time interval is more damaging than the same dose given during a longer period of time (Muller 1927).

Radiation induces tissue injury at the cellular level. Most susceptible tissues are those with a higher percentage of dividing cells (Brown and Rzucidlo 2011). To protect healthy tissue surrounding tumor, molecular hydrogen $\left(\mathrm{H}_{2}\right)$ may afford reasonable protection since it neutralizes detrimental ROS, especially the hydroxyl radical (Qian et al. 2010).

\section{Inflammation}

Oxidative and nitrosative stress is usually tightly connected with inflammatory response and metabolic processes accompanied by the generation of highly reactive free radicals. ROS and reactive nitrogen species (RNS), such as superoxide, nitric oxide, peroxinitrite and hydrogen peroxide and other ROS/RNS-related compounds can react with other substrates. Under physiological conditions, these are counterbalanced by an array of defense mechanisms. In situations where defense is compromised, ROS and RNS may react with fatty acids, proteins and DNA and damage them. Antioxidants (like coenzyme Q10, vitamin C and E, and glutathione) and innate antioxidant enzymes (e.g. superoxide dismutase, glutathione peroxidase and catalase) regulate oxidative and nitrosative reactions. Some proteins function as antioxidants by binding ROS and RNS, e.g. acute phase proteins such as albumin, transferrin, haptoglobin and ceruloplasmin. Oxidative and nitrosative stress occurs as a result of lower activity of tissue antioxidant enzymes and cause oxidative damage to membrane lipids (lipid peroxidation) and DNA, as well as nitrosative damage to proteins (Maes 2009a,b). Activation of inflammatory reaction and oxidative and nitrosative stress pathways is a key pathophysiological factor of a number of diseases including inflammation and depression (Maes 2008).

\section{Rheumatoid arthritis}

Rheumatoid arthritis (RA) is a chronic inflammation associated with an increased risk of atherosclerosis, which can result in cardiovascular disease and increased mortality. While the mechanisms responsible for the onset of RA remain unclear, ROS play a significant role in the pathogenesis of RA (Mirshafiey and Mohsenzadegan 2008, Gelderman et al. 2007).

ROS play a central role both upstream and downstream of NF- $\mathrm{kB}$ and TNF $\alpha$ pathways, which are considered to play a central role in the inflammatory response. Among ROS, the hydroxyl radical is the most harmful. Molecular hydrogen has been proposed as a selective ROS scavenger. Recently, it has been shown that $\mathrm{H}_{2}$ is beneficial when administered along with the conventional therapy of RA and is able to reduce oxidative stress in the patients. Especially in the early stage of RA, $\mathrm{H}_{2}$ showed significant therapeutic potential, which also seemed to determine diagnostic and treatment strategy (Ishibashi 2013).

\section{Endothelium injury: role and impact of ROS}

The endothelium plays an essential role in maintaining of cardiovascular function, and early changes in endothelial function are indicators of cardiovascular morbidity and mortality (Okruhlicova et al. 2012, Triggle et al. 2012). Important functional role of endothelium is represented by the control of blood flow, angiogenesis, inflammation, platelet aggregation, and vascular remodeling, as well as by control of metabolism (Stewart et al. 2010, Slezak et al. 2015).

$\mathrm{I} / \mathrm{R}$ injury is dependent not only on the events within cardiomyocytes, but the endothelium is an active participant as well. The endothelium is the major source of the ephemeral molecule of nitric oxide (NO). Under normal conditions, NO generation elicits vasodilation, which has beneficial, protective effects during I/R, likely by influencing oxygen consumption, platelet aggregation, (Radomski et al. 1987) leukocyte adhesion, and free radical scavenging. Paradoxically, in high concentrations, NO may potentiate ROS-mediated toxicity by promoting the formation of highly reactive species, such as peroxynitrite (Wang and Zweier 1996, Turer and Hill 2010).

The equilibrium of the nitroso/redox balance between RNS and ROS is crucial for the function of cardiomyocytes. The key role of nitric oxide synthases (NOSs) in the maintenance of the nitroso/redox balance is obvious. Uncoupled endothelial NOS has been suggested 
to shift the balance from nitric oxide to ROS production, contributing to increased oxidative stress within the myocardium (Zhang et al. 2012).

Endothelium is not only an important source of NO, but also of numerous other signaling molecules including the putative endothelium-derived hyperpolarizing factor, prostacyclin, and hydrogen peroxide, which have both vasodilating and vasoconstricting properties. It modulates flow-mediated vasodilatation as well as influences mitogenic activity, platelet aggregation, and neutrophil adhesion. These early effects are followed by endothelial cells proliferation and obstruction of myocardial capillary lumen (Gyenes 1998).

It has been postulated that damage to the microvascular components begins with the injury of endothelial cells within blood capillaries of the heart. Endothelial damage leads to an acute inflammatory reaction and to activation of the coagulation mechanisms with consequent fibrin deposition. The activation of macrophages and monocytes during the inflammatory process (Slezak et al. 2015) results in the continuous secretion of cytokines and growth factors, including tumor necrosis factor (TNF), interleukin IL-1, IL-6, IL-18, monocytes chemotactic factor. Besides induction of adhesion molecules, up-regulation of some cytokines (namely IL-6 and IL-8) has been observed after endothelial cell irradiation in a time- and dose-related manner (Burger et al. 1998, Van der Meeren et al. 1999).

The redox imbalance between nitric oxide and superoxide generated in the endothelium is thought to play a pivotal role in the development of endothelial dysfunction. $\mathrm{H}_{2} \mathrm{O}_{2}$ is known to exert both beneficial and detrimental effects on the vasculature. Nonetheless, the influence of the hydroxyl radical, a by-product of $\mathrm{H}_{2} \mathrm{O}_{2}$ decay, is unclear, and there is no direct evidence that the hydroxyl radicals impair endothelial function in conduit arteries (Sakai et al. 2014). Molecular hydrogen may protect the vasculature from shear stress-derived detrimental ROS, such as hydroxyl radical, by maintaining the NO-mediated vasomotor response (Sakai et al. 2014).

\section{Protective effect of molecular hydrogen as a scavenger of hydroxyl radical}

Acute oxidative stress causes serious damage to tissues, and persistent oxidative stress is one of the causes of many diseases including cancer, cardiovascular pathologies and the aging process. In fact, molecular hydrogen has a potential as an effective antioxidant for many medical applications (Ohsawa et al. 2007, Ohta 2012, 2014). It was also demonstrated that hydrogen-rich saline significantly improved post-ischemic functional recovery of rat hearts (Chang and Toledo-Pereyra 2013).

To attenuate the harmful effects of oxidative stress and ROS, one can directly eliminate them by medical gases such as carbon monoxide (CO), hydrogen sulphide $\left(\mathrm{H}_{2} \mathrm{~S}\right)$, and $\mathrm{H}_{2}$, or one can induce ROS-resistant proteins and antioxidant enzymes to antagonize oxidative stress (Noda et al. 2011).

Molecular hydrogen is the smallest gas molecule consisting of two protons and two electrons. Hydrogen is combustible when the concentration is $4-75 \%$. On the other hand, $\mathrm{H}_{2}$ is a stable gas that can react only with oxide radical ion $\left({ }^{\circ} \mathrm{O}^{\top}\right)$ and hydroxyl radical $\left({ }^{\circ} \mathrm{OH}\right)$ in water with low reaction rate constants (Buxton et al. 1988). Molecular hydrogen neutralizes detrimental ROS, especially the hydroxyl radical (Ohta 2014).

Molecular hydrogen was originally thought to be an inert gas in mammalian cells, however, previous studies showed that this is not always the case. It neutralizes the hydroxyl radical and peroxynitrite inside the cells and acts as an antioxidant to protect the cells against oxidative stress (Ishibashi 2013, Ohta 2014). Subsequently, $\mathrm{H}_{2}$ was shown to exhibit multiple functions including anti-inflammatory, anti-apoptotic, anti-allergic, and antioxidant properties, as well as regulation of cell differentiation and involvement in energy metabolism. Molecular hydrogen also regulates various signal transduction pathways and the expression of many genes (Hanaoka et al. 2011, Ohta 2011).

Numerous studies have suggested that $\mathrm{H}_{2}$ has the potential for a variety of therapeutic and preventive applications (Ohta 2014). In addition to extensive animal experiments, several clinical studies examining the efficacy of $\mathrm{H}_{2}$ have been reported including doubleblinded clinical studies in patients with Parkinson's disease and rheumatism (Yoritaka et al. 2013, Ishibashi et al. 2014).

As mentioned before, $\mathrm{H}_{2}$ reacts with strong oxidants such as hydroxyl radical in cells, and is potentially proposed for preventive and therapeutic applications. Molecular hydrogen has a number of advantages exhibiting extensive effects: $\mathrm{H}_{2}$ rapidly diffuses into tissues and cells, and it is mild enough neither to affect metabolic redox reactions nor to affect signaling reactive oxygen species. Therefore, no adverse effects of $\mathrm{H}_{2}$ should be expected. In addition to a growing 
number of results obtained from animal experiments, extensive clinical examinations have been reported or are currently running. Since most drugs act specifically to reach their targets, $\mathrm{H}_{2}$ seems to differ from conventional pharmaceutical drugs. Due to its great efficacy and lack of adverse effects, $\mathrm{H}_{2}$ has a promising potential for a clinical use to treat many diseases (Ohta 2014).

A major breakthrough in hydrogen research occurred after Ohsawa et al. (2007) reported a prominent effect of molecular hydrogen on a rat model of cerebral infarction. Rats were subjected to left middle cerebral artery occlusion and placed in 2-4\% hydrogen gas chamber. Results showed significantly smaller infarction volumes compared to controls. The authors attributed the hydrogen effect to the specific activity of scavenging hydroxyl radical $\left({ }^{\bullet} \mathrm{OH}\right)$. They also demonstrated that hydrogen scavenges peroxynitrite but to a lesser extent (Oshawa et al. 2007).

\section{Ways of $\mathrm{H}_{2}$ applications}

There are several methods how to apply $\mathrm{H}_{2}$. Inhalation of $\mathrm{H}_{2}$ gas, ingestion by drinking $\mathrm{H}_{2}$-rich water ( $\mathrm{H}_{2}$-water), injecting $\mathrm{H}_{2}$-rich saline $\left(\mathrm{H}_{2}\right.$-saline), taking $\mathrm{H}_{2}$ bath, or dropping $\mathrm{H}_{2}$-saline into the eyes. The numerous studies of its biological and medical benefits revealed that $\mathrm{H}_{2}$ reduces oxidative stress not only by direct reactions with strong oxidants, but also indirectly by regulating various gene expressions (Ohta 2014).

$\mathrm{H}_{2}$ can be dissolved in water up to $0.8 \mathrm{mM}$ (1.6 ppm, wt $/ \mathrm{vol}$ ) under higher pressure. $\mathrm{H}_{2}$ rapidly disappears, it penetrates the glass and plastic walls of any vessel. However, aluminum containers are able to retain hydrogen gas at atmospheric pressure at refrigerator temperature for relatively long time (Ohta 2014).

More recent studies have also shown that hydrogen is able to reduce ROS in vitro, as a result of its proposed ability to scavenge the hydroxyl radical, "the most potent oxidant known to mankind" (Dole et al. 1975, Xie et al. 2010). Electrolyzed-reduced water scavenges active oxygen species and protects DNA from oxidative damage (Shirahata et al. 1997).

Inhalation of $1-4 \%(\mathrm{v} / \mathrm{v}) \mathrm{H}_{2}$ gas is effective for the treatment of ischemia/reperfusion injury (Hayashida et al. 2008). Recently, inhalation of $1.3 \% \mathrm{H}_{2}$ gas from a premixed gas was shown to protect neurons in a cardiac arrest model. However, the mechanism of how such a low concentration of $\mathrm{H}_{2}$ exerts the positive effects is not known.

Oral administration is safe and convenient, $\mathrm{H}_{2}$ in water tends to escape over time and some $\mathrm{H}_{2}$ is lost in the stomach or intestine, making it difficult to control the concentration of $\mathrm{H}_{2}$ administered. Administration of $\mathrm{H}_{2}$ $v i a$ an injectable hydrogen saline $\left(\mathrm{H}_{2}\right.$-rich saline) vehicle may allow the delivery of more accurate concentrations of $\mathrm{H}_{2}$ (Schoenfeld et al. 2011, Kajimura et al. 2010).

Medical gasses like $\mathrm{CO}, \mathrm{NO}$ and $\mathrm{H}_{2} \mathrm{~S}$ are generated by endogenous enzymatic systems. Pharmaceutical research has taken advantage of these systems to design exogenous molecules to simulate those generated endogenously; however, mammals lack their own enzyme to produce $\mathrm{H}_{2}$ (Kajimura et al. 2010).

Other findings indicate that $\mathrm{H}_{2}$ released from intestinal bacteria can suppress inflammation. $\mathrm{H}_{2}$ also mediates the suppression of colon inflammation induced by dextran sodium sulfate (Kajiya et al. 2009a).

Hydrogenized saline can also be administered either by intraperitoneal injection or drip infusion. Hydrogen water is mostly given ad libitum. Hydrogen gas is usually given by inhaling 1-4\% hydrogen gas, which is below the explosion level (4\%). Continuous exposure to hydrogen gas and ad libitum per os administration of hydrogen water modulated signaling pathways and gene expressions in different manners in mice (Shirahata et al. 1997).

The number of clinical trials is increasing every year. In most diseases, the effect of hydrogen has been reported with hydrogen water or hydrogen gas, which was followed by confirmation of the effect with hydrogen-rich saline or Krebs-Henseleit solution. Recently, Zálešák et al. (2016) performed pilot experiments demonstrating that hydrogen-rich KrebsHenseleit solution administered in a mode of postconditioning improved post-ischemic recovery in isolated rat hearts. The improvement in functional recovery was coupled with a significant reduction in infarct size. Histological analysis revealed a substantial decrease in hemorrhage and necrosis within the ischemic zone. Application of hydrogen during early reperfusion appears to be cardioprotective and to facilitate anti-infarct potential of postconditioning without additional antistunning protection (Zálešák et al. 2016).

\section{Possible molecular mechanisms of $\mathrm{H}_{2}$ action}

Iuchi et al. (2016) elucidated one of the molecular mechanisms by which $\mathrm{H}_{2}$ mediates signal transduction and gene expression. The results suggested that low concentrations of $\mathrm{H}_{2}$ modulated $\mathrm{Ca}^{2+}$ signal transduction and regulated gene expression by modifying 
the production of oxidized phospholipid species (Iuchi et al. 2016).

Among genes involved in signaling pathways, the proportion of those involved in $\mathrm{Ca}^{2+}$ signaling was lower in the selected genes than in those in the entire genome indicating that $\mathrm{H}_{2}$ regulates fewer components of the $\mathrm{Ca}^{2+}$ signaling pathways. This was consistent with the finding that $\mathrm{H}_{2} \mathrm{OxPAPC}$ decreased $\mathrm{Ca}^{2+}$ signaling. In contrast, the proportion of genes belonging to the mitogen-activated protein kinase (MAPK) signaling was higher indicating that $\mathrm{H}_{2}$ regulates more components of MAPK signal transduction pathways (Iuchi et al. 2016).

Low concentrations of $\mathrm{H}_{2}$ contribute to various signal transduction pathways via oxidized phospholipid species. These data are consistent with the previous studies showing the $\mathrm{Ca}^{2+}$-dependent regulation by transcription factors: cAMP response element-binding protein (CREB) is activated via phosphorylation by a calmodulin-dependent kinase (CaMK) in a $\mathrm{Ca}^{2+}$ dependent manner, and nuclear factor of activated T-cells (NFAT) is dephosphorylated by calcineurin in a $\mathrm{Ca}^{2+}$ dependent manner, translocates to the nucleus, and then acts as a transcription factor with its partner proteins, e.g. activator protein 1 (AP-1), CREB, or nuclear factorkappa B (NF-kB). Thus, $\mathrm{H}_{2}$-dependent oxidized mediators or putative antagonists could be associated with transcriptional regulation via $\mathrm{Ca}^{2+}$ signaling (Iuchi et al. 2016, Christl et al. 1992). Low concentrations of $\mathrm{H}_{2}$ modulate $\mathrm{Ca}^{2+}$ signal transduction and regulate gene expression by modifying the production of oxidized phospholipid species. Data provide important insights into one of the molecular mechanisms by which $\mathrm{H}_{2}$ mediates gene expression (Iuchi et al. 2016, Christl et al. 1992, Dixon et al. 2013, Ohno et al. 2012).

Understanding the exact molecular mechanisms of the effects of hydrogen will elucidate and clarify the pros and cons of hydrogen therapy. It will also lead to the development of another therapeutic modality to modulate the master regulator(s). Hydrogen exhibits statistically significant effects in patients but they are usually not as conspicuous as those observed in animal models. It might be caused by the difference in species, and to a certain extend by a technical difficulty in preparing a high concentration of hydrogen-rich water every day (Fujita $e t$ al. 2009). A similar dose-response effect is also observed in inhaled hydrogen gas (Ohsawa et al. 2007, Hayashida et al. 2008, Fukuda et al. 2007). Hydrogen-rich water generally shows a more prominent effect than hydrogen gas, although the amount of hydrogen taken up by hydrogen water is $\sim 100$ times less than that given by hydrogen gas (Ito et al. 2012). Gastric secretion of ghrelin may partly account for that difference (Ichihara et al. 2015).

Effects of hydrogen in various situations have been attributed to four major molecular mechanisms: a specific scavenging activity to neutralize hydroxyl radical, a scavenging activity to neutralize peroxynitrite, modulation of altered gene expressions, and signalmodulating activities. The four mechanisms are not mutually exclusive and some of them may be causally associated with other mechanisms.

The first molecular mechanism identified for hydrogen appears to be its specific scavenging activity (Ohsawa et al. 2007). As was shown, oxidative stress markers like 8-OHdG, 4-hydroxyl-2-nonenal (4-HNE), malondialdehyde (MDA), and thiobarbituric acid reactive substances (TBARSs) are decreased in all examined patients and animals, as hydrogen can easily dissipate by exhalation. Hydrogen in drinking water is able to stay in human and rodent body for less than $10 \mathrm{~min}$. Hydrogen, however, can bind to glycogen, and its stay is prolonged in rat liver after food intake (Kamimura et al. 2011).

\section{Peroxynitrite and $\mathrm{H}_{2}$ effect}

Reaction of ${ }^{\circ} \mathrm{O}_{2}^{-}$with ${ }^{-} \mathrm{NO}$ generates peroxynitrite, which is a very active nitrogen species (Radi 2013). Therefore, another molecular mechanism of hydrogen effect is its peroxynitrite scavenging activity. Although hydrogen cannot eliminate peroxynitrite as efficiently as hydroxyl radical in vitro (Ohsawa et al. 2007), hydrogen can markedly reduce NO-induced production of nitrotyrosine in rodents (Chen et al. 2010, Yu et al. 2011, Zhang et al. 2011, Zhu et al. 2011, Hanaoka et al. 2011). NO is a gaseous molecule that also exerts therapeutic effects including relaxation of blood vessels and inhibition of platelet aggregation (Thomas et al. 2008). However, NO is also toxic at higher concentrations because it leads to production of nitrotyrosine, which compromises protein functions. A part of hydrogen effects may thus be attributed to the reduced production of nitrotyrosine (Zhang et al. 2011, Zhu et al. 2011).

Specific scavenging activities of hydroxyl radical and peroxynitrite, however, cannot fully explain the anti-inflammatory and anti-apoptotic effects, which should involve a number of fine-tuned signaling pathways. It was shown that hydrogen suppresses signaling pathways in allergies (Itoh et al. 2009) and 
inflammation (Itoh et al. 2011) without directly scavenging reactive oxygen/nitrogen species. Signaling molecules that are modulated by hydrogen include RAS (Chen et al. 2013).

Despite of positive action of $\mathrm{H}_{2}$ as a ROS scavenger there remain some unanswered questions. First, no dose-response effect of hydrogen has been observed. Hydrogen has been administered to animals and humans in the forms of hydrogen gas, hydrogen-rich water, hydrogen-rich saline, instillation, and dialysis solution. As hydrogen mostly disappears within about $10 \mathrm{~min}$ by dissipation via exhalation, an individual is exposed to $2.8 \%$ hydrogen only for about $10 \mathrm{~min}$ (Ohno et al. 2012).

The second unanswered question concerns intestinal production of hydrogen gas in rodents and humans. Although no mammalian cells can produce hydrogen endogenously, it is produced by intestinal bacteria carrying hydrogenase in both animals and humans. Humans are able to produce a maximum of 12 liters of hydrogen in the intestines (Christl et al. 1992, Strocchi and Levitt 1992). Specific pathogen-free animals are different from aseptic animals and carry intestinal bacteria that produce hydrogen. The amount of hydrogen taken by water or gas is much less than that produced by intestinal bacteria, but the exogenously administered hydrogen demonstrates a prominent effect. Kajiya et al. (2009b) reported that drinking hydrogen-rich water was more effective than the restitution of hydrogenasepositive bacteria in intestine. If intestinal hydrogen is as effective as the other hydrogen administration methods, we can easily increase hydrogen concentrations in our bodies by an alfa-glucosidase inhibitor, acarbose, an ingredient of curry, turmeric, or a nonabsorbable synthetic disaccharide, lactulose (Shimouchi et al. 2009, Corazza et al. 1992, Chen et al. 2011). Therefore, it is necessary to elucidate in more details molecular basis of hydrogen effects in more details.

Administration of $\mathrm{H}_{2}$ serves as an antioxidant treatment, and it has also been shown to have antiinflammatory, cytoprotective and signal modulatory effects.

Anti-inflammatory effect. Hydrogen has been described to possess anti-inflammatory properties. Gharib et al. (2001) observed these anti-inflammatory effects in a mouse model of chronic liver inflammation induced by the parasite Schistosoma mansoni. Hyperbaric hydrogen treatment was able to improve liver hemodynamics and reduce portal hypertension, as well as to reduce liver fibrosis by attenuating inflammatory cytokines (Gharib et al. 2001).

Administration of $\mathrm{H}_{2}$ revealed that oxidoreduction-related genes were upregulated in many pathological models. Administration of hydrogen downregulated pro-inflammatory cytokines including tumor necrosis-factor-(TNF-), interleukin-(IL-) $1 \beta$, IL-6, IL-12, interferon-(IFN-), and high mobility group box 1 (HMGB1) (Buchholz et al. 2008, 2011, Kajiya et al. 2009a,b, Mao et al. 2009, Zheng et al. 2009, Nakao et al. 2010, Liu et al. 2010, Hayashi et al. 2011, Yoon et al. 2011, Song et al. 2011, Huang et al. 2011, Sun et al. 2009, 2011, Wang et al. 2011, Ji et al. 2011, Liu et al. 2011, Shen et al. 2011, Yang et al. 2011).

Hydrogen also downregulated nuclear factors including nuclear factor kappa B, JNK, and proliferation cell nuclear antigen and caspases (Itoh et al. 2009, Sun et al. 2009). Other important molecules including vascular endothelial growth factor (Ye et al. 2008), MMP2 and MMP9 (Chen et al. 2010), brain natriuretic peptide, intercellular-adhesion-molecule- 1 and myeloperoxidase, B-cell lymphoma 2 and Bcl-2-associated X protein, MMP3 and MMP13, cyclooxygenase 2, neuronal nitric oxide synthase, connexins (Hugyecz et al. 2011, Ohno et al. 2012), and others were studied as well (Sun et al. 2011, Kamimura et al. 2011). However, most molecules are probably passengers that are secondarily changed by hydrogen administration, and some are potentially direct targets of hydrogen effects.

Cytoprotective effect of $\mathrm{H}_{2}$. Although hydrogen has been strongly implicated in reduction of oxidative stress, it has been proposed that hydrogen affects signaling mechanisms and can also induce cytoprotection (Itoh et al. 2011, Sun et al. 2009). The exact mechanism when and how hydrogen is able to provide cytoprotection is unknown. It can potentiate other antioxidant enzymes such as superoxide dismutase and catalase (Xie et al. 2010). It is also proposed that hydrogen can confer cytoprotection by preventing the activation of caspase-3, which can subsequently reduce apoptosis (Sun et al. 2009). Shi et al. (2012) also proposed that molecular hydrogen may be able to affect signal transduction by interacting with metalloproteins, since metal ions can be a possible binding site for hydrogen.

It was also confirmed that hydrogen was able to modulate signal transduction, however, further studies need to be conducted to determine exactly under what circumstances hydrogen can be a signal modulator (Itoh et al. 2011). Recently, it has been reported that hydrogen 
may be able to block signaling pathways as a result of its ability to reduce the levels of ROS. It has also been shown that molecular hydrogen is able to inhibit the TNF- $\alpha / \mathrm{NF}-\kappa \beta$ pathway as well as the Ras-ERK1/ 2-MEK1/2 and Akt pathways (Ito et al. 2012, Chen et al. 2013). Possible gene regulatory effects were also reported (Qin et al. 2012, Chen et al. 2013). The suppression of these pathways by hydrogen was demonstrated in neointimal hyperplasia models in rats. Further investigation of these mechanisms is needed since these pathways are involved in inflammatory responses, gene regulation, and apoptosis. The possibilities to regulate these pathways are quite substantial (Chen et al. 2013, Ohta 2011).

Signal modulatory effect. It still remains to confirm that hydrogen exerts its beneficial effect as a signal modulator. Hydrogen modulates miRNA expression (Liu et al. 2013, Wei et al. 2015), such as expression of miR-9, miR-21, and miR-199, and possibly many others (Kura et al. 2016). Analysis of miRNA profiles of hippocampal neurons during $I / R$ injury revealed that hydrogen inhibits I/R-induced expression of the miR-200 family by reducing ROS production, which has led to suppression of cell death (Wei et al. 2015). However, modulation of miRNA expression cannot solely explain all the biological effects mediated by hydrogen. Mechanisms underlying modulated miRNA expression remain to be elucidated.

As reported by Ichihara et al. (2015) the effects of $\mathrm{H}_{2}$ have been observed in practically all organs covering 31 disease categories that can be subdivided into 166 disease models, human diseases, treatment-associated pathologies, and pathophysiological conditions of plants with a predominance of oxidative stress-mediated diseases and inflammatory diseases (Ichihara et al. 2015). Administration of $\mathrm{H}_{2}$ to astronauts by either inhalation or drinking hydrogen water may potentially be a novel preventative/therapeutic strategy to prevent radiationinduced adverse events (Schoenfeld et al. 2011, Kajiya et al. 2009b, Ohta 2011) (Fig. 2).

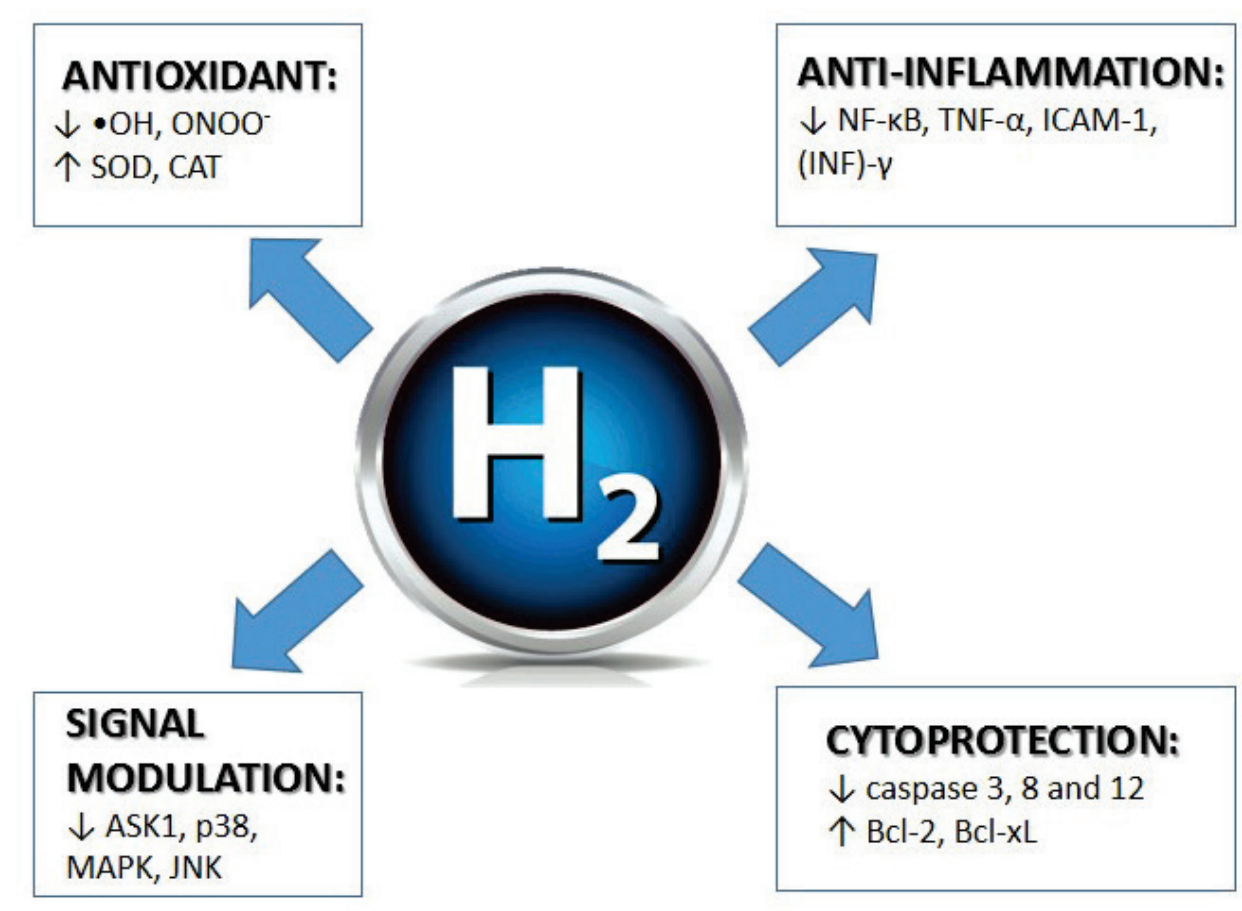

Fig. 2. Antioxidative, anti-inflammatory, cytoprotective and signal modulatory effect of $\mathrm{H}_{2}$ administration.

\section{Conclusion}

Review aims to summarize our present knowledge on strategy how to control oxidative stress by molecular hydrogen. Despite some positive results in discovering the effective antioxidant that would be able to mitigate the adverse effect of excessive production of reactive oxygen species, search for the proper compounds is still ongoing. Recently it was shown by numerous animal and clinical studies that hydrogen is an important physiological regulatory factor with antioxidant, antiinflammatory, anti-apoptotic and signal modulatory protective effects on cells and organs. Application of molecular hydrogen in situations with excessive 
production of free radicals and, in particular, hydroxyl radicals is relatively simple and effective, therefore, it deserves special attention.

Therapeutic application of hydrogen has been performed by different delivery methods including inhalation, drinking hydrogen rich water and/or infusion hydrogen-saturated solutions. This review summarizes currently available data regarding the protective role of hydrogen and provides an outline of recent advances in research of the use of hydrogen as a therapeutic modality in diverse models of pathologies associated with oxidative stress.

The exact mechanisms of how molecular hydrogen operates still need to be explored. The missing links of how hydrogen is involved in cell signaling and activation or suppression of transduction pathways, and how hydrogen can reduce inflammation are all important. Moreover, the efficiency of specific concentrations in various disease models needs to be determined.

\section{Conflict of Interest}

There is no conflict of interest.

\section{Acknowledgements}

This study was supported by grants APVV-0241-11, VEGA 2/0021/15 and partially NIH R37 HL051045, VEGA SR 2/0201/15, APVV-0102-11 and APVV-150376.

\section{References}

BELL EL, KLIMOVA TA, EISENBART J, SCHUMACKER PT, CHANDEL NS: Mitochondrial reactive oxygen species trigger hypoxia-inducible factor-dependent extension of the replicative life span during hypoxia. Mol Cell Biol 27: 5737-5745, 2007.

BERGONIÉ J, TRIBONDEAU L: De quelques résultats de la radiotherapie et essai de fixation d'une technique rationnelle. C R Séances Acad Sci 143: 983-985, 1906.

BJELAKOVIC G, NIKOLOVA D, GLUUD LL, SIMONETTI RG, GLUUD C: Mortality in randomized trials of antioxidant supplements for primary and secondary prevention: systematic review and meta-analysis. JAMA 297: 842-857, 2007.

BOLLI R, PATEL BS, JEROUDI MO, LAI EK, MCCAY PB: Demonstration of free radical generation in "stunned" myocardium of intact dogs with the use of the spin trap alpha-phenyl N-tert-butyl nitrone. $J$ Clin Invest $\mathbf{8 2}$ : 476-485, 1988.

BOLLI R, JEROUDI MO, PATEL BS, ARUOMA OI, HALLIWELL B, LAI EK, MCCAY PB: Marked reduction of free radical generation and contractile dysfunction by antioxidant therapy begun at the time of reperfusion. Evidence that myocardial "stunning" is a manifestation of reperfusion injury. Circ Res 65: 607-622, 1989.

BREWER AC, MUSTAFI SB, MURRAY TV, RAJASEKARAN NS, BENJAMIN IJ: Reductive stress linked to small HSPs, G6PD, and Nrf2 pathways in heart disease. Antioxid Redox Signal 18: 1114-1127, 2013.

BROWN KR, RZUCIDLO E: Acute and chronic radiation injury. J Vasc Surg 53: 15S-21S, 2011.

BUCHHOLZ BM, KACZOROWSKI DJ, SUGIMOTO R, YANG R, WANG Y, BILLIAR TR, MCCURRY KR, BAUER AJ, NAKAO A: Hydrogen inhalation ameliorates oxidative stress in transplantation induced intestinal graft injury. Am J Transplant 8: 2015-2024, 2008.

BUCHHOLZ BM, MASUTANI K, KAWAMURA T, PENG X, TOYODA Y, BILLIAR TR, BAUER AJ, NAKAO A: Hydrogen-enriched preservation protects the isogeneic intestinal graft and amends recipient gastric function during transplantation. Transplantation 92: 985-992, 2011.

BURGER A, LÖFFLER H, BAMBERG M, RODEMANN HP: Molecular and cellular basis of radiation fibrosis. Int $J$ Radiat Biol 73: 401-408, 1998.

BUXTON GV, GREENSTOCK CL, HELMAN WP, ROSS AB: Critical view of rate constants for reactions of hydrated electrons, hydrogen atoms and hydroxyl radicals $(\cdot \mathrm{OH} / \bullet \mathrm{OH}-)$ in aqueous solution. $J$ Phys Chem Ref Data 17: 513-886, 1988.

CHANG WJ, TOLEDO-PEREYRA LH: The potential benefits of hydrogen-rich saline in ischemia and reperfusion injury. J Surg Res 180: 248-249, 2013. 
CHEN CH, MANAENKO A, ZHAN Y, LIU WW, OSTROWKI RP, TANG J, ZHANG JH: Hydrogen gas reduced acute hyperglycemia-enhanced hemorrhagic transformation in a focal ischemia rat model. Neuroscience 169: 402-414, 2010.

CHEN X, ZUO Q, HAI Y, SUN XJ: Lactulose: an indirect antioxidant ameliorating inflammatory bowel disease by increasing hydrogen production. Med Hypotheses 76: 325-327, 2011.

CHEN Y, JIANG J, MIAO H, CHEN X, SUN X, LI Y: Hydrogen-rich saline attenuates vascular smooth muscle cell proliferation and neointimal hyperplasia by inhibiting reactive oxygen species production and inactivating the Ras-ERK1/2-MEK1/2 and Akt pathways. Int J Mol Med 31: 597-606, 2013.

CHRISTL SU, MURGATROYD PR, GIBSON GR, CUMMINGS JH: Production, metabolism, and excretion of hydrogen in the large intestine. Gastroenterology 102: 1269-1277, 1992.

CITRIN D, COTRIM AP, HYODO F, BAUM BJ, KRISHNA MC, MITCHELL JB: Radioprotectors and mitigators of radiation-induced normal tissue injury. Oncologist 15: 360-371, 2010.

COLLINS Y, CHOUCHANI ET, JAMES AM, MENGER KE, COCHEMÉ HM, MURPHY MP: Mitochondrial redox signalling at a glance. $J$ Cell Sci 125: 801-806, 2012.

CORAZZA GR, SORGE M, STROCCHI A, BENATI G, DI SARIO A, TREGGIARI EA, BRUSCO G, GASBARRINI G: Non-absorbable antibiotics and small bowel bacterial overgrowth. Ital J Gastroenterol 24: 4-9, 1992.

DIXON BJ, TANG J, ZHANG JH: The evolution of molecular hydrogen: a noteworthy potential therapy with clinical significance. Med Gas Res 3: 10, 2013.

DOLE M, WILSON FR, FIFE WP: Hyperbaric hydrogen therapy: a possible treatment for cancer. Science 190: 152-154, 1975.

DOWNEY JM, COHEN MV: A really radical observation. Basic Res Cardiol 101: 190-191, 2006.

ENDO J, SANO M, KATAYAMA T, HISHIKI T, SHINMURA K, MORIZANE S, MATSUHASHI T, KATSUMATA Y, ZHANG Y, ITO H, NAGAHATA Y, MARCHITTI S, NISHIMAKI K, WOLF AM, NAKANISHI H, HATTORI F, VASILIOU V, ADACHI T, OHSAWA I, TAGUCHI R, HIRABAYASHI Y, OHTA S, SUEMATSU M, OGAWA S, FUKUDA K: Metabolic remodeling induced by mitochondrial aldehyde stress stimulates tolerance to oxidative stress in the heart. Circ Res 105: 1118-1127, 2009.

ERKENS R, KRAMER CM, LÜCKSTÄDT W, PANKNIN C, KRAUSE L, WEIDENBACH M, DIRZKA J, KRENZ T, MERGIA E, SUVORAVA T, KELM M, CORTESE-KROTT MM: Left ventricular diastolic dysfunction in Nrf2 knock out mice is associated with cardiac hypertrophy, decreased expression of SERCA2a, and preserved endothelial function. Free Radic Biol Med 89: 906-917, 2015.

FLAHERTY JT, PITT B, GRUBER JW, HEUSER RR, ROTHBAUM DA, BURWELL LR, GEORGE BS, KEREIAKES DJ, DEITCHMAN D, GUSTAFSON N, BRINKER JA, BECKER LC, MANCINI GBJ, TOPOL E, WERNS SW: Recombinant human superoxide dismutase (h-SOD) fails to improve recovery of ventricular function in patients undergoing coronary angioplasty for acute myocardial infarction. Circulation 89: 19821991, 1994.

FUJITA K, SEIKE T, YUTSUDO N, OHNO M, YAMADA H, YAMAGUCHI H, SAKUMI K, YAMAKAWA Y, KIDO MA, TAKAKI A, KATAFUCHI T, TANAKA Y, NAKABEPPU Y, NODA M: Hydrogen in drinking water reduces dopaminergic neuronal loss in the 1-methyl-4-phenyl-1,2,3,6-tetrahydropyridine mouse model of Parkinson's disease. PLoS One 4: e7247, 2009.

FUKUDA K, ASOH S, ISHIKAWA M, YAMAMOTO Y, OHSAWA I, OHTA S: Inhalation of hydrogen gas suppresses hepatic injury caused by ischemia/reperfusion through reducing oxidative stress. Biochem Biophys Res Commun 361: 670-674, 2007.

GARG AD, DUDEK AM, FERREIRA GB, VERFAILLIE T, VANDENABEELE P, KRYSKO DV, MATHIEU C, AGOSTINIS P: ROS-induced autophagy in cancer cells assists in evasion from determinants of immunogenic cell death. Autophagy 9: 1292-1307, 2013.

GELDERMAN KA, HULTQVIST M, OLSSON LM, BAUER K, PIZZOLLA A, OLOFSSON P, HOLMDAHL R: Rheumatoid arthritis: the role of reactive oxygen species in disease development and therapeutic strategies. Antioxid Redox Signal 9: 1541-1567, 2007. 
GHARIB B, HANNA S, ABDALLAHI OM, LEPIDI H, GARDETTE B, DE REGGI M: Anti-inflammatory properties of molecular hydrogen: investigation on parasite-induced liver inflammation. C R Acad Sci III 324: 719-724, 2001.

GO YM, JONES DP: Thiol/disulfide redox states in signaling and sensing. Crit Rev Biochem Mol Biol 48: 173-181, 2013.

GYENES G: Radiation-induced ischemic heart disease in breast cancer-a review. Acta Oncol 37: 241-246, 1998.

HALESTRAP AP, CLARKE SJ, KHALIULIN I: The role of mitochondria in protection of the heart by preconditioning. Biochim Biophys Acta 1767: 1007-1031, 2007.

HALLIWELL B, GUTTERIDGE JM: Biologically relevant metal ion-dependent hydroxyl radical generation. An update. FEBS Lett 307: 108-112, 1992.

HANAOKA T, KAMIMURA N, YOKOTA T, TAKAI S, OHTA S: Molecular hydrogen protects chondrocytes from oxidative stress and indirectly alters gene expressions through reducing peroxynitrite derived from nitric oxide. Med Gas Res 1: 18, 2011.

HATOUM OA, OTTERSON MF, KOPELMAN D, MIURA H, SUKHOTNIK I, LARSEN BT, SELLE RM, MOULDER JE, GUTTERMAN DD: Radiation induces endothelial dysfunction in murine intestinal arterioles via enhanced production of reactive oxygen species. Arterioscler Thromb Vasc Biol 26: 287-294, 2006.

HAYASHI T, YOSHIOKA T, HASEGAWA K, MIYAMURA M, MORI T, UKIMURA A, MATSUMURA Y, ISHIZAKA N: Inhalation of hydrogen gas attenuates left ventricular remodeling induced by intermittent hypoxia in mice. Am J Physiol Heart Circ Physiol 301: H1062-H1069, 2011.

HAYASHIDA K, SANO M, OHSAWA I, SHINMURA K, TAMAKI K, KIMURA K, ENDO J, KATAYAMA T, KAWAMURA A, KOHSAKA S, MAKINO S, OHTA S, OGAWA S, FUKUDA K: Inhalation of hydrogen gas reduces infarct size in the rat model of myocardial ischemia-reperfusion injury. Biochem Biophys Res Commun 373: 30-35, 2008.

HONG JH, CHIANG CS, CAMPBELL IL, SUN JR, WITHERS HR, MCBRIDE WH: Induction of acute phase gene expression by brain irradiation. Int J Radiat Oncol Biol Phys 33: 619-626, 1995.

HUANG Y, XIE K, LI J, XU N, GONG G, WANG G, YU Y, DONG H, XIONG L: Beneficial effects of hydrogen gas against spinal cord ischemia-reperfusion injury in rabbits. Brain Res 1378: 125-136, 2011.

HUGYECZ M, MRACSKÓ E, HERTELENDY P, FARKAS E, DOMOKI F, BARI F: Hydrogen supplemented air inhalation reduces changes of prooxidant enzyme and gap junction protein levels after transient global cerebral ischemia in the rat hippocampus. Brain Res 1404: 31-38, 2011.

ICHIHARA M, SOBUE S, ITO M, ITO M, HIRAYAMA M, OHNO K: Beneficial biological effects and the underlying mechanisms of molecular hydrogen - comprehensive review of 321 original articles. Med Gas Res 5: 12, 2015

ISHIBASHI T: Molecular hydrogen: new antioxidant and anti-inflammatory therapy for rheumatoid arthritis and related diseases. Curr Pharm Des 19: 6375-6381, 2013.

ISHIBASHI T, SATO B, SHIBATA S, SAKAI T, HARA Y, NARITOMI Y, KOYANAGI S, HARA H, NAGAO T: Therapeutic efficacy of infused molecular hydrogen in saline on rheumatoid arthritis: a randomized, doubleblind, placebo-controlled pilot study. Int Immunopharmacol 21: 468-473, 2014

ITO M, HIRAYAMA M, YAMAI K, GOTO S, ITO M, ICHIHARA M, OHNO K: Drinking hydrogen water and intermittent hydrogen gas exposure, but not lactulose or continuous hydrogen gas exposure, prevent 6-hydorxydopamine-induced Parkinson's disease in rats. Med Gas Res 2: 15, 2012.

ITOH T, FUJITA Y, ITO M, MASUDA A, OHNO K, ICHIHARA M, KOJIMA T, NOZAWA Y, ITO M: Molecular hydrogen suppresses FcepsilonRI-mediated signal transduction and prevents degranulation of mast cells. Biochem Biophys Res Commun 389: 651-656, 2009.

ITOH T, HAMADA N, TERAZAWA R, ITO M, OHNO K, ICHIHARA M, NOZAWA Y, ITO M: Molecular hydrogen inhibits lipopolysaccharide/interferon $\gamma$-induced nitric oxide production through modulation of signal transduction in macrophages. Biochem Biophys Res Commun 411: 143-149, 2011. 
IUCHI K, IMOTO A, KAMIMURA N, NISHIMAKI K, ICHIMIYA H, YOKOTA T, OHTA S: Molecular hydrogen regulates gene expression by modifying the free radical chain reaction-dependent generation of oxidized phospholipid mediators. Sci Rep 6: 18971, 2016.

JAZWA A, CUADRADO A: Targeting heme oxygenase-1 for neuroprotection and neuroinflammation in neurodegenerative diseases. Curr Drug Targets 11: 1517-1531, 2010.

JI Q, HUI K, ZHANG L, SUN X, LI W, DUAN M: The effect of hydrogen-rich saline on the brain of rats with transient ischemia. J Surg Res 168: e95-e101, 2011.

JONES DP: Radical-free biology of oxidative stress. Am J Physiol Cell Physiol 295: C849-C868, 2008.

JONES DP, LIANG Y: Measuring the poise of thiol/disulfide couples in vivo. Free Radic Biol Med 47: 1329-1338, 2009.

KAJIMURA M, FUKUDA R, BATEMAN RM, YAMAMOTO T, SUEMATSU M: Interactions of multiple gas-transducing systems: hallmarks and uncertainties of $\mathrm{CO}, \mathrm{NO}$, and $\mathrm{H}_{2} \mathrm{~S}$ gas biology. Antioxid Redox Signal 13: 157-192, 2010.

KAJIYA M, SATO K, SILVA MJ, OUHARA K, DO PM, SHANMUGAM KT, KAWAI T: Hydrogen from intestinal bacteria is protective for Concanavalin A-induced hepatitis. Biochem Biophys Res Commun 386: 316-321, 2009a.

KAJIYA M, SILVA MJ, SATO K, OUHARA K, KAWAI T: Hydrogen mediates suppression of colon inflammation induced by dextran sodium sulfate. Biochem Biophys Res Commun 386: 11-15, $2009 \mathrm{~b}$.

KAMIMURA N, NISHIMAKI K, OHSAWA I, OHTA S: Molecular hydrogen improves obesity and diabetes by inducing hepatic FGF21 and stimulating energy metabolism in db/db mice. Obesity (Silver Spring) 19: 13961403, 2011.

KLANDORF H, VAN DYKE K: Oxidative and nitrosative stresses: their role in health and disease in man and birds. In: Oxidative Stress - Molecular Mechanisms and Biological Effects. V LUSHCHAK (ed.), chapter 3, InTech, Rijeka, Croatia, 2012.

KURA B, YIN C, KUKREJA RC, SLEZAK J: Cardiac specific miRNAs expression levels in irradiated rat myocardium after treatment with selected drugs. In: New Frontiers in Basic Cardiovascular Research: a France - New EU Members, 3-6 July 2016, Paris, 2016, poster no. 54.

KYRKANIDES S, MOORE AH, OLSCHOWKA JA, DAESCHNER JC, WILLIAMS JP, HANSEN JT, KERRY O'BANION M: Cyclooxygenase-2 modulates brain inflammation-related gene expression in central nervous system radiation injury. Brain Res Mol Brain Res 104: 159-169, 2002.

LI J, LOUKILI N, ROSENBLATT-VELIN N, PACHER P, FEIHL F, WAEBER B, LIAUDET L: Peroxynitrite is a key mediator of the cardioprotection afforded by ischemic postconditioning in vivo. PLoS One 8: e70331, 2013.

LI L, ISHDORJ G, GIBSON SB: Reactive oxygen species regulation of autophagy in cancer: implications for cancer treatment. Free Radic Biol Med 53: 1399-1410, 2012.

LIN MT, BEAL MF: Mitochondrial dysfunction and oxidative stress in neurodegenerative diseases. Nature 443: 787-795, 2006.

LIU GD, ZHANG H, WANG L, HAN Q, ZHOU SF, LIU P: Molecular hydrogen regulates the expression of miR-9, miR-21 and miR-199 in LPS-activated retinal microglia cells. Int J Ophthalmol 6: 280-285, 2013.

LIU Q, SHEN WF, SUN HY, FAN DF, NAKAO A, CAI JM, YAN G, ZHOU WP, SHEN RX, YANG JM, SUN XJ: Hydrogen-rich saline protects against liver injury in rats with obstructive jaundice. Liver Int 30: 958-968, 2010.

LIU Y, LIU W, SUN X, LI R, SUN Q, CAI J, KANG Z, LV S, ZHANG JH, ZHANG W: Hydrogen saline offers neuroprotection by reducing oxidative stress in a focal cerebral ischemia-reperfusion rat model. Med Gas Res 1: $15,2011$.

MAES M: The cytokine hypothesis of depression: inflammation, oxidative \& nitrosative stress (IO\&NS) and leaky gut as new targets for adjunctive treatments in depression. Neuro Endocrinol Lett 29: 287-291, 2008.

MAES M: Inflammatory and oxidative and nitrosative stress pathways underpinning chronic fatigue, somatization and psychosomatic symptoms. Curr Opin Psychiatry 22: 75-83, 2009a.

MAES M: "Functional" or "psychosomatic" symptoms, e.g. a flu-like malaise, aches and pain and fatigue, are major features of major and in particular of melancholic depression. Neuro Endocrinol Lett 30: 564-573, $2009 \mathrm{~b}$. 
MAJZUNOVA M, DOVINOVA I, BARANCIK M, CHAN JY: Redox signaling in pathophysiology of hypertension. J Biomed Sci 20: 69, 2013.

MAO YF, ZHENG XF, CAI JM, YOU XM, DENG XM, ZHANG JH, JIANG L, SUN XJ: Hydrogen-rich saline reduces lung injury induced by intestinal ischemia/reperfusion in rats. Biochem Biophys Res Commun 381: 602-605, 2009.

MATEJÍKOVÁ J, KUCHARSKÁ J, PINTÉROVÁ M, PANCZA D, RAVINGEROVÁ T: Protection against ischemiainduced ventricular arrhythmias and myocardial dysfunction conferred by preconditioning in the rat heart: involvement of mitochondrial K-ATP channels and reactive oxygen species. Physiol Res 58: 9-19, 2009.

MATÉS JM, SEGURA JA, ALONSO FJ, MÁRQUEZ J: Oxidative stress in apoptosis and cancer: an update. Arch Toxicol 86: 1649-1665, 2012.

MIRSHAFIEY A, MOHSENZADEGAN M: The role of reactive oxygen species in immunopathogenesis of rheumatoid arthritis. Iran J Allergy Asthma Immunol 7: 195-202, 2008.

MULLER HJ: Artificial transmutation of the gene. Science 66: 84-87, 1927.

NAKAO A, KACZOROWSKI DJ, WANG Y, CARDINAL JS, BUCHHOLZ BM, SUGIMOTO R, TOBITA K, LEE S, TOYODA Y, BILLIAR TR, MCCURRY KR: Amelioration of rat cardiac cold ischemia/reperfusion injury with inhaled hydrogen or carbon monoxide, or both. J Heart Lung Transplant 29: 544-553, 2010.

NODA M, FUJITA K, LEE CH, YOSHIOKA T: The principle and the potential approach to ROS-dependent cytotoxicity by non-pharmaceutical therapies: optimal use of medical gases with antioxidant properties. Curr Pharm Des 17: 2253-2263, 2011.

OHNO K, ITO M, ICHIHARA M, ITO M: Molecular hydrogen as an emerging therapeutic medical gas for neurodegenerative and other diseases. Oxid Med Cell Longev 2012: 353152, 2012.

OHSAWA I, ISHIKAWA M, TAKAHASHI K, WATANABE M, NISHIMAKI K, YAMAGATA K, KATSURA K, KATAYAMA Y, ASOH S, OHTA S: Hydrogen acts as a therapeutic antioxidant by selectively reducing cytotoxic oxygen radicals. Nat Med 13: 688-694, 2007.

OHTA S: Recent progress toward hydrogen medicine: potential of molecular hydrogen for preventive and therapeutic applications. Curr Pharm Des 17: 2241-2252, 2011.

OHTA S: Molecular hydrogen is a novel antioxidant to efficiently reduce oxidative stress with potential for the improvement of mitochondrial diseases. Biochim Biophys Acta 1820: 586-594, 2012.

OHTA S: Molecular hydrogen as a preventive and therapeutic medical gas: initiation, development and potential of hydrogen medicine. Pharmacol Ther 144: 1-11, 2014.

OKRUHLICOVA L, KNEZL V, NAVAROVA J, SOTNIKOVA R, BERNATOVA I, FRIMMEL K, SLEZAK J: Inflammation-induced structural alterations of endothelium contribute to increased susceptibility of the heart to ischemia/reperfusion injury. Acta Physiol 206 (Suppl 693): P208, 2012.

PATEL RS, GHASEMZADEH N, EAPEN DJ, SHER S, ARSHAD S, KO YA, VELEDAR E, SAMADY H, ZAFARI AM, SPERLING L, VACCARINO V, JONES DP, QUYYUMI AA: Novel biomarker of oxidative stress is associated with risk of death in patients with coronary artery disease. Circulation 133: 361-369, 2016.

PECHANOVA O, SIMKO F: Chronic antioxidant therapy fails to ameliorate hypertension: potential mechanisms behind. J Hypertens 27 (Suppl 6): S32-S36, 2009.

PENNA C, RASTALDO R, MANCARDI D, RAIMONDO S, CAPPELLO S, GATTULLO D, LOSANO G, PAGLIARO P: Post-conditioning induced cardioprotection requires signaling through a redox-sensitive mechanism, mitochondrial ATP-sensitive $\mathrm{K}+$ channel and protein kinase $\mathrm{C}$ activation. Basic Res Cardiol 101: 180-189, 2006.

QIAN L, CAO F, CUI J, WANG Y, HUANG Y, CHUAI Y, ZAHO L, JIANG H, CAI J: The potential cardioprotective effects of hydrogen in irradiated mice. J Radiat Res 51: 741-747, 2010.

QIN ZX, YU P, QIAN DH, SONG MB, TAN H, YU Y, LI W, WANG H, LIU J, WANG Q, SUN XJ, JIANG H, ZHU JK, LU W, HUANG L: Hydrogen-rich saline prevents neointima formation after carotid balloon injury by suppressing ROS and the TNF- $\alpha / \mathrm{NF}-\mathrm{kB}$ pathway. Atherosclerosis 220: 343-350, 2012.

RADI R: Peroxynitrite, a stealthy biological oxidant. J Biol Chem 288: 26464-26472, 2013. 
RADOMSKI MW, PALMER RM, MONCADA S: Endogenous nitric oxide inhibits human platelet adhesion to vascular endothelium. Lancet 2: 8567, 1987.

RAVINGEROVÁ T: Intrinsic defensive mechanisms in the heart: a potential novel approach to cardiac protection against ischemic injury. Gen Physiol Biophys 26: 3-13, 2007.

RAVINGEROVÁ T, ČARNICKÁ S, NEMČEKOVÁ M, LEDVÉNYIOVÁ V, ADAMEOVÁ A, KHANDELWAL VK, ZÁLEŠÁK M, KOLÁŘ F: The impact of lifestyle-related risk factors on cardiac response to ischemia and possibilities to restore impaired ischemic tolerance. Physiol Res 61 (Suppl 2): S1-S10, 2012.

REUTER S, GUPTA SC, CHATURVEDI MM, AGGARWAL BB: Oxidative stress, inflammation, and cancer: how are they linked? Free Radic Biol Med 49: 1603-1616, 2010.

RISTOW M, ZARSE K: How increased oxidative stress promotes longevity and metabolic health: the concept of mitochondrial hormesis (mitohormesis). Exp Gerontol 45: 410-418, 2010.

SAKAI T, SATO B, HARA K, HARA Y, NARITOMI Y, KOYANAGI S, HARA H, NAGAO T, ISHIBASHI T: Consumption of water containing over $3.5 \mathrm{mg}$ of dissolved hydrogen could improve vascular endothelial function. Vasc Health Risk Manag 10: 591-597, 2014.

SCHOENFELD MP, ANSARI RR, ZAKRAJSEK JF, BILLIAR TR, TOYODA Y, WINK DA, NAKAO A: Hydrogen therapy may reduce the risks related to radiation-induced oxidative stress in space flight. Med Hypotheses 76: 117-118, 2011.

SCHOENFELD MP, ANSARI RR, NAKAO A, WINK D: A hypothesis on biological protection from space radiation through the use of new therapeutic gases as medical counter measures. Med Gas Res 2: 8, 2012.

SHEN L, WANG J, LIU K, WANG C, WANG C, WU H, SUN Q, SUN X, JING H: Hydrogen-rich saline is cerebroprotective in a rat model of deep hypothermic circulatory arrest. Neurochem Res 36: 1501-1511, 2011.

SHI P, SUN W, SHI P: A hypothesis on chemical mechanism of the effect of hydrogen. Med Gas Res 2: $17,2012$.

SHIMOUCHI A, NOSE K, TAKAOKA M, HAYASHI H, KONDO T: Effect of dietary turmeric on breath hydrogen. Dig Dis Sci 54: 1725-1729, 2009.

SHIRAHATA S, KABAYAMA S, NAKANO M, MIURA T, KUSUMOTO K, GOTOH M, HAYASHI H, OTSUBO K, MORISAWA S, KATAKURA Y: Electrolyzed-reduced water scavenges active oxygen species and protects DNA from oxidative damage. Biochem Biophys Res Commun 234: 269-274, 1997.

SIES H: Oxidative stress: oxidants and antioxidants. Exp Physiol 82: 291-295, 1997.

SLEZAK J, KURA B, RAVINGEROVÁ T, TRIBULOVA N, OKRUHLICOVA L, BARANCIK M: Mechanisms of cardiac radiation injury and potential preventive approaches. Can J Physiol Pharmacol 93: 737-753, 2015.

SONG G, TIAN H, LIU J, ZHANG H, SUN X, QIN S: $H_{2}$ inhibits TNF- $\alpha$-induced lectin-like oxidized LDL receptor-1 expression by inhibiting nuclear factor $\kappa \mathrm{B}$ activation in endothelial cells. Biotechnol Lett 33: 1715-1722, 2011.

STEINHUBL SR: Why have antioxidants failed in clinical trials? Am J Cardiol 101: 14D-19D, 2008.

STEWART FA, HOVING S, RUSSELL NS: Vascular damage as an underlying mechanism of cardiac and cerebral toxicity in irradiated cancer patients. Radiat Res 174: 865-869, 2010.

STROCCHI A, LEVITT MD: Maintaining intestinal H2 balance: credit the colonic bacteria. Gastroenterology 102: 1424-1426, 1992.

SUN Q, KANG Z, CAI J, LIU W, LIU Y, ZHANG JH, DENOBLE PJ, TAO H, SUN X: Hydrogen-rich saline protects myocardium against ischemia/reperfusion injury in rats. Exp Biol Med (Maywood) 234: 1212-1219, 2009.

SUN Q, CAI J, ZHOU J, TAO H, ZHANG JH, ZHANG W, SUN XJ: Hydrogen-rich saline reduces delayed neurologic sequelae in experimental carbon monoxide toxicity. Crit Care Med 39: 765-769, 2011.

THOMAS DD, RIDNOUR LA, ISENBERG JS, FLORES-SANTANA W, SWITZER CH, DONZELLI S, HUSSAIN P, VECOLI C, PAOLOCCI N, AMBS S, COLTON CA, HARRIS CC, ROBERTS DD, WINK DA: The chemical biology of nitric oxide: implications in cellular signaling. Free Radic Biol Med 45: 18-31, 2008.

TORMOS KV, ANSO E, HAMANAKA RB, EISENBART J, JOSEPH J, KALYANARAMAN B, CHANDEL NS: Mitochondrial complex III ROS regulate adipocyte differentiation. Cell Metab 14: 537-544, 2011.

TRIGGLE CR, SAMUEL SM, RAVISHANKAR S, MAREI I, ARUNACHALAM G, DING H: The endothelium: influencing vascular smooth muscle in many ways. Can J Physiol Pharmacol 90: 713-738, 2012. 
TSUKAGOSHI H, BUSCH W, BENFEY PN: Transcriptional regulation of ROS controls transition from proliferation to differentiation in the root. Cell 143: 606-616, 2010.

TURER AT, HILL JA: Pathogenesis of myocardial ischemia-reperfusion injury and rationale for therapy. Am J Cardiol 106: 360-368, 2010.

VAN DER MEEREN A, SQUIBAN C, GOURMELON P, LAFONT H, GAUGLER MH: Differential regulation by IL-4 and IL-10 of radiation-induced IL-6 and IL-8 production and ICAM-1 expression by human endothelial cells. Cytokine 11: 831-838, 1999.

VANDEN HOEK T, BECKER LB, SHAO ZH, LI CQ, SCHUMACKER PT: Preconditioning in cardiomyocytes protects by attenuating oxidant stress at reperfusion. Circ Res 86: 541-548, 2000.

VAZIRI ND, RODRÍGUEZ-ITURBE B: Mechanisms of disease: oxidative stress and inflammation in the pathogenesis of hypertension. Nat Clin Pract Nephrol 2: 582-593, 2006.

WANG F, YU G, LIU SY, LI JB, WANG JF, BO LL, QIAN LR, SUN XJ, DENG XM: Hydrogen-rich saline protects against renal ischemia/reperfusion injury in rats. J Surg Res 167: e339-e344, 2011.

WANG P, ZWEIER JL: Measurement of nitric oxide and peroxynitrite generation in the postischemic heart. Evidence for peroxynitrite-mediated reperfusion injury. J Biol Chem 271: 29223-29230, 1996.

WEI R, ZHANG R, XIE Y, SHEN L, CHEN F: Hydrogen suppresses hypoxia/reoxygenation-induced cell death in hippocampal neurons through reducing oxidative stress. Cell Physiol Biochem 36: 585-598, 2015.

WEST AP, BRODSKY IE, RAHNER C, WOO DK, ERDJUMENT-BROMAGE H, TEMPST P, WALSH MC, CHOI Y, SHADEL GS, GHOSH S: TLR signalling augments macrophage bactericidal activity through mitochondrial ROS. Nature 472: 476-480, 2011.

XIA Y, ZWEIER JL: Substrate control of free radical generation from xanthine oxidase in the postischemic heart. J Biol Chem 270: 18797-18803, 1995.

XIE K, YU Y, PEI Y, HOU L, CHEN S, XIONG L, WANG G: Protective effects of hydrogen gas on murine polymicrobial sepsis via reducing oxidative stress and HMGB1 release. Shock 34: 90-97, 2010.

YANG X, GUO L, SUN X, CHEN X, TONG X: Protective effects of hydrogen-rich saline in preeclampsia rat model. Placenta 32: 681-686, 2011.

YE J, LI Y, HAMASAKI T, NAKAMICHI N, KOMATSU T, KASHIWAGI T, TERUYA K, NISHIKAWA R, KAWAHARA T, OSADA K, TOH K, ABE M, TIAN H, KABAYAMA S, OTSUBO K, MORISAWA S, KATAKURA Y, SHIRAHATA S: Inhibitory effect of electrolyzed reduced water on tumor angiogenesis. Biol Pharm Bull 31: 19-26, 2008.

YOON KS, HUANG XZ, YOON YS, KIM SK, SONG SB, CHANG BS, KIM DH, LEE KJ: Histological study on the effect of electrolyzed reduced water-bathing on UVB radiation-induced skin injury in hairless mice. Biol Pharm Bull 34: 1671-1677, 2011.

YORITAKA A, TAKANASHI M, HIRAYAMA M, NAKAHARA T, OHTA S, HATTORI N: Pilot study of $\mathrm{H}_{2}$ therapy in Parkinson's disease: a randomized double-blind placebo-controlled trial. Mov Disord 28: 836-839, 2013.

YU P, WANG Z, SUN X, CHEN X, ZENG S, CHEN L, LI S: Hydrogen-rich medium protects human skin fibroblasts from high glucose or mannitol induced oxidative damage. Biochem Biophys Res Commun 409: 350-355, 2011.

ZÁLEŠÁK M: Hypoxic postconditioning and possibilities to improve its cardioprotective potential by molecular hydrogen. In: Ischemic Conditioning and Targeting Reperfusion Injury: a 30 Year Voyage of Discovery. Barcelona, Spain, May 12-13, 2016. (J Mol Cell Cardiol in press 2016.)

ZHANG Y, SUN Q, HE B, XIAO J, WANG Z, SUN X: Anti-inflammatory effect of hydrogen-rich saline in a rat model of regional myocardial ischemia and reperfusion. Int $J$ Cardiol 148: 91-95, 2011.

ZHANG Y, TOCCHETTI CG, KRIEG T, MOENS AL: Oxidative and nitrosative stress in the maintenance of myocardial function. Free Radic Biol Med 53: 1531-1540, 2012.

ZHENG X, MAO Y, CAI J, LI Y, LIU W, SUN P, ZHANG JH, SUN X, YUAN H: Hydrogen-rich saline protects against intestinal ischemia/reperfusion injury in rats. Free Radic Res 43: 478-484, 2009.

ZHOU R, YAZDI AS, MENU P, TSCHOPP J: A role for mitochondria in NLRP3 inflammasome activation. Nature 469: 221-225, 2011. 
ZHU WJ, NAKAYAMA M, MORI T, NAKAYAMA K, KATOH J, MURATA Y, SATO T, KABAYAMA S, ITO S: Intake of water with high levels of dissolved hydrogen $\left(\mathrm{H}_{2}\right)$ suppresses ischemia-induced cardio-renal injury in Dahl salt-sensitive rats. Nephrol Dial Transplant 26: 2112-2118, 2011.

ZWEIER JL: Measurement of superoxide-derived free radicals in the reperfused heart. Evidence for a free radical mechanism of reperfusion injury. $J$ Biol Chem 263: 1353-1357, 1988. 